\title{
Wychowanie przez estetykę. Idea antropozoficzna w wybranych dziełach Karola Homolacsa
}

Ars naturae ministra. Temporis natura filia ${ }^{1}$.

\begin{abstract}
The article is an attempt to grasp the concept of anthroposophical aesthetics. The ideas of Rudolf Steiner, the founder of anthroposophy, repeatedly touched the area of human creative activity. The anthroposophical activity (including lectures and publications) of Karol Homolacs, professor of the State Higher School of Artistic Industry and the Academy of Fine Arts in Krakow, seems to be an excellent example of the application of these ideas in theory and practice.
\end{abstract}

Keywords: anthroposophy, Rudolf Steiner, Karol Homolacs, anthroposophical aesthetics

W

roku 1938 w Warszawie na Walnym Zjeździe Delegatów Polskiego Towarzystwa Antropozoficznego Karol Homolacs wygłosił wykład Wychowawcze znaczenie sztuki². Z tej krótkiej informacji wypływają dwa ważne fakty, określające specyfikę teoretycznej pracy profesora Państwowej Wyższej Szkoły Przemysłu Artystycznego i ASP w Krakowie ${ }^{3}$ : z jednej strony zaangażowanie Homolacsa

${ }^{1}$ Chymische Hochzeit: Christiani Rozencreitz. [Sztuka jest służącą natury. Natura jest córą czasu].

2 Tekst ukazał się w formie broszurki w tym samym roku.

${ }^{3}$ Karol Homolacs w latach 1921-1933 wykładał w Państwowej Wyższej Szkole Przemysłu Artystycznego i ASP w Krakowie. 
w prężnie rozwijający się wówczas na ziemiach polskich ruch antropozoficzny ${ }^{4}$, z drugiej - podporządkowanie mu lub inaczej, wpisanie w antropozoficzne propozycje Rudolfa Steinera własnych dotychczasowych poszukiwań, jakie rozpoczął malarz dużo wcześniej, w pracach nad kategorią ornamentu w sztuce.

Zagadnienie estetyki antropozoficznej, wspomnianej tu w ramach prac teoretycznych Karola Homolacsa, wymaga poruszenia dwóch dopełniających się wzajemnie aspektów: zasady estetyczno-filozoficznego budowania pojęcia sztuki przez antropozofię oraz proces rozwijania i nauczania estetycznego postrzegania rzeczywistości, czyli pedagogiki antropozoficznej. Jako przykłady wypowiedzi samego Homolacsa, unaoczniające siłę wpływu antropozoficznych idei na światopogląd malarza, spośród szeregu dzieł teoretycznych jego autorstwa szczególnie wyróżniają się dwie publikacje, jakie ujrzały światło dzienne w roku 1929 i 1936 dwie książki starannie wydane w Krakowie: Studium formy barwy i światła: w zwiqzzku z metodykq ćwiczeń rysunkowo-malarskich obejmujq̨cq zakres szkół ogólnokształcacych i artystycznych (1929) i Zasada harmonii w sztuce i w życiu (1936). Pierwsza z wymienionych była wydana niedługo po oficjalnym wstąpieniu Homolacsa do Polskiego Towarzystwa Antropozoficznego (PTA) i, jak się wydaje, stanowiła próbę połączenia osobistych badań teoretyka z zapoznanym systemem nauczania Rudolfa Steinera, czemu powtórnie da wyraz na Walnym Zjedzie Delegatów w 1938 roku. Druga wspomniana książka została wydana nakładem własnym i okazała się być swoistą próbą określenia stanu współczesnej sztuki a poprzez to kondycji współczesnej Homolaczowi Polski. Jest to traktat o byciu w świecie, o jego kategoryzacji przez człowieka, o wpływie idei antropozoficznych na współczesny świat, o próbie określenia świata i człowieka w nim poprzez sztukę. Ten ciekawy przekaz okazał się na tyle istotny, że w corocznych sprawozdaniach z działalności PTA można przeczytać o tym, iż dla jego członków są do kupienia następujące pozycje książkowe: Dr. Steinera, O żywej istocie antropozofii /Listy do członków/ 4.50 zł; Alberta Steffena, Ku czci Rudolfa Steinera - 3 zł oraz „broszurę członka Koła Krakowskiego prof. Karola Homolacza p.t. Zasada harmonii w sztuce $i$ w życiu cena - zł. 2.50”5.

Antropozofia jako systemowe ujęcie duchowego aspektu człowieka i świata nie stawiała podstawowego pytania, jakie nurtowało estetyków początku XX wie$\mathrm{ku}^{6}$ - czym jest sztuka? Brakowało tu założeń teoretycznych i twardych definicji budujących czy określających postawy estetyczne. Sztuka w ujęciu antropozoficz-

${ }^{4}$ Karol Homolacs należał do Powszechnego Towarzystwa Antropozoficznego (Allgemeine Anthroposophische Gesellschaft, AAG), Krakowskiego Koła Polskiego Towarzystwa Antropozoficznego im. Jana Łaskiego. Kartę członkowską nr 47 otrzymał w roku 1924. W tym samym czasie do PTA wstąpiła także żona artysty, Wanda Homolacs.

${ }^{5}$ Komunikaty Polskiego Towarzystwa Antropozoficznego, Warszawa, listopad 1938 rok, Goetheanum Archiv A.02.008.001.

${ }^{6}$ Zob. B. Dziemidok, Główne kontrowersje estetyki współczesnej, Wydawnictwo Naukowe PWN, Warszawa 2012. 
nym była integralną częścią, składową procesu duchowego rozwoju człowieka. Ponieważ należała do dziedziny praktyki, taką też rolę pełniła. Prawdopodobnie właśnie dlatego z jednej strony przyciągała świadomych swojego talentu artystów (Wassily Kandinsky ${ }^{7}$, Hilma af Klint ${ }^{8}$, Andriej Bieły ${ }^{9}$ ), a z drugiej, pobudzała do działania antropozofów bez wyraźnych zadatków artystycznych. Tworzone dzieło sztuki - obraz, tekst literacki, kompozycja muzyczna - było rezultatem wtajemniczenia. Powstające lub powstałe dzieło zawsze podlegało świadomemu procesowi kreacji, zatem nie był to eksperyment, jaki przeprowadzał na sobie twórca, chcąc dotrzeć do istoty pragnienia wewnętrznego, do jego określenia i tym samym wypowiedzi natury wewnętrznej. To, co nosiło miano dzieła sztuki, było w projekcji autora swego rodzaju obracającym się kołem powtórzeń, mnemoniką obrazów duchowych, porządkowaniem treści już określonych czy inaczej zdobytych w trakcie ćwiczeń duchowych, swoistą notatką, zapisaną w obszarze pozamaterialnym. Nasuwa się w tym miejscu porównanie z pojęciem wirtualnej strony obrazu Georges’a Didi-Hubermana ${ }^{10}$. Wydaje się, że porównanie to jest możliwe w przypadku dzieł artystów „zaangażowanych ezoterycznie”11 właśnie dlatego, że dotyczy przestrzeni objawienia uświęconego bytu. Treść pozoobrazowa, o której mówi Didi-Huberman, treść ujęta poza reprezentacją, w przypadku sztuki antropozoficznej jest oświetlana nie promieniami słonecznymi, wpadającymi przez małe okienko celi ${ }^{12}$, lecz predyspozycją wewnętrznego oglądu patrzącego na obraz,

${ }^{7}$ Zob.: W. Kandyński, O duchowości w sztuce, wstęp M. Bill, tłum. S. Fijałkowski, Państwowa Galeria Sztuki, Łódź 1996; Kandinsky und München. Begegnungen und Wandlungen 1896-1914, ed. A. Zweite, Prestel Verlag, München 1982; D. Oboleńska, De Imaginatione. O эзотерической имагинации в русской культуре начала $X X$ века, Wydawnictwo Uniwersytetu Gdańskiego, Gdańsk 2014; Б. Соколов, Василий Кандинский. Эпоха великой духовности. Живопись. Поэзия. Театр. Личность, Букс МАрт, Москва 2016 i in.

${ }^{8}$ Zob. D. Oboleńska, M. Rzeczycka, Ezoteryczne inspiracje Hilmy af Klint (1862-1944), „Przegląd religioznawczy” 2016, nr 1.

9 The occult in Russian and Soviet culture, ed. by B. Rosenthal, Cornell University Press 1997; T. Gut, Andrej Belyj. Symbolismus, Anthroposophie Ein Weg, Rudolf Steiner Verlag, Dornach 1997; D. Oboleńska, Путь к посвящению. Антропософские мотивы в романах Андрея Белого, Wydawnictwo Uniwersytetu Gdańskiego, Gdańsk 2009 i in.

${ }^{10}$ G. Didi-Huberman, Przed obrazem. Pytanie o cele historii sztuki, tłum. B. Brzezicka, Słowo/obraz terytoria, Gdańsk 2011.

${ }^{11}$ Pisałam o tym w artykule poświęconym twórczości Kazimierza Malewicza, Emblems as hieroglyphs of the imagination. “The Black Square” by Kazimir Malevich, „Studia Humanistyczne AGH” 2017, t. 16/4.

12 „Kiedy dziś wchodzimy do cichej celi, elektryczne oświetlenie skierowane na dzieło nie przeciwdziała wystarczająco efektowi zaciemnienia, który narzuca się w pierwszej chwili. Obok fresku znajduje się małe okienko wychodzące na wschód; dobiegające z niego światło obejmuje naszą twarz i zasłania oczekiwany spektakl. Namalowany pod światło fresk Fra Angelico w pewien sposób zakrywa to, co widoczne. [...] Kiedy wzrok przyzwyczaja się do ciemności, to wrażenie dodatkowo się pogłębia: fresk «rozjaśnia się» tylko po to, by znów niemal zniknąć w bieli ściany. [...] mocne oświetlenie obrazu, to obnażenie, czy też katharsis, miało uczynić fresk bardziej tajemniczym - niczym ciało uświęcone w kryształowej wodzie - tak by misterium, 
z czego wynika, że promieniem oświetlającym staje się sam odbiorca. Aktywuje on za pomocą obrazu rozpoznawalne doznania duchowe, czym rozpoczyna sekwencję powtarzalności doświadczenia wewnętrznego, ponownie wzbogacając ogląd rzeczywistości pozamaterialnej - stan katharsis, nie przypadkowego, lecz świadomie przywołanego. Zatem, jeśli dzieło sztuki pełni rolę swoistego sygnału wywoławczego dla adresata, nie może być z natury swojej eksperymentem artysty, lecz stanowi zamierzoną projekcję twórczą. To mało odkrywcze stwierdzenie jest niezwykle ważkie dla określenia istotowości sztuki antropozoficznej z dwóch powodów: po pierwsze, wyodrębnia ją na tle poszukiwań twórczych początku $\mathrm{XX}$ wieku, a po drugie, co istotniejsze, ujawnia jej podporządkowany charakter.

Zatem z jednej strony, sztukę antropozoficzną cechują stałe zasady funkcjonowania przy określeniu ich dokładnej kolejności: dzieło sztuki jest wyrazem indywidualnego poznania duchowego i stanowi formę szczególnego sygnału dla zaangażowanego odbiorcy. „Sztuka jest najpierw twórcza, zaś dopiero potem piękna [...]"13. W tym przypadku zaangażowanego odbiorcę rozumiem jako człowieka mającego do czynienie bądź z wyjątkowym przeżyciem duchowym, bądź zaznajomionego z systemami ezoterycznymi, lub jedno i drugie.

Idea antropozoficzna ściśle opisuje i charakteryzuje duchową „konstrukcję” mikrokosmosu i makrokosmosu.

Mamy więc trzy pierwotne części składowe ludzkiej natury, jakie ma każdy człowiek, nawet w najbardziej pierwotnym stopniu rozwoju, a do tego jaźń. [...] Określmy więc trzy pierwotne części składowe natury ludzkiej, ciało fizyczne, eteryczne, astralne oraz jaźń ${ }^{14}$.

Wraz z czterema częściami funkcjonują jeszcze trzy: duch-jaźń, duch-życie, duch-człowiek. Ciało fizyczne, eteryczne i astralne, pełnią istotną funkcję - dają możliwość wejrzenia kolejno w świat fizyczny, eteryczny i astralny. Powstająca w ten sposób struktura „istnienia w światach” określona jest przez kilka podstawowych związków - porządek duchowego wejrzenia podlega pewnej etapowości, a istnienie etapów określa obopólny wpływ na siebie. Proces oglądu światów duchowych związany jest z kategorią twórczej kontemplacji i twórczego odtworzenia w świadomości kontemplującego, czyli z procesem zrozumienia dokonanego oglądu - wtajemniczeniem. Rezultatem takiej pracy twórczej może być powstające w kolejnym etapie dzieło sztuki. Zdolność człowieka do kreatywnego odtwarzania

które od początku wymyka się reprezentacji, mogło stać się wirtualne”. G. Didi-Huberman, Przed obrazem..., s. 13, 21.

13 J.W. Goethe, O niemieckiej architekturze, w: Teoretycy, artyści i krytycy o sztuce 17001870, wybór, przedm. i koment. E. Grabska, M. Poprzęcka, PWN, Warszawa 1974, s. 219.

${ }^{14}$ R. Steiner, Teozofia różokrzyżowców, tłum. M. Waśniewski, Genesis, Gdynia 1996, s. 24. Zob. również: idem, U bram teozofii, tłum. M. Waśniewski, Genesis, Gdynia 1997. 
wszystkich możliwych światów oglądowych Steiner wysoko cenił ${ }^{15}$, czemu dał wyraz w swoich wykładach oraz we własnej aktywności twórczej: obrazy, rzeźby, stworzenie nowego systemu taneczno-ruchowego, zwanego eurytmią, projekt i budowa centrum antropozoficznego Goetheanum w Dornach (Szwajcaria) ${ }^{16}$.

Proces wejrzenia w światy duchowe wiąże się nieodłącznie z umiejętnością adepta podporządkowania temu własnej struktury świadomości, jej transformacji, nastawionej na możliwość kontemplacji poprzez akty wyobrażeniowe, w czym można dostrzec podstawę pracy twórczej będącej jednocześnie pewnym etapem w procesie wtajemniczenia. Zatem, tak jak zostało to już powiedziane, sztuka w systemie antropozofii nie stanowi samodzielnego, odrębnego elementu, lecz jest mocno związana z całym procesem inicjacyjnym i jest bezwarunkowo określeniem, lub inaczej, wypowiedzią na temat stopnia wtajemniczenia duchowego. Opisują to trzy antropozoficzne stopnie wyższego poznania: imaginacja (poznanie imaginatywne), inspiracja (poznanie inspiratywne) i intuicja (poznanie intuitywne).

Stopień poznania imaginatywnego udostępnia adeptowi ogląd obrazów duchowych pojawiających się na poziomie wyższej świadomości, poza wpływem zmysłów jako takich. Poznanie imaginatywne łączy w sobie obiektywny świat duchowy i subiektywny świat twórcy ${ }^{17}$. Projekcje z obszaru aktywności fantazjującej działają w światach niższych, poza obszarem imaginacji.

Poznanie inspiratywne hierarchicznie jest nadrzędne w stosunku do poznania imaginatywnego.

Inspiracja daje wrażenia, ,ja” zaś tworzy pojęcia. Gdybyśmy chcieli porównać ten świat z czymś zmysłowym, to moglibyśmy przytoczyć jedynie świat dźwięków dostępny słuchowi. Nie mamy tu jednak do czynienia z dźwiękami takimi, jak w muzyce dostępnej zmysłom, lecz z „dźwiękami czysto duchowymi”. Tu zaczynamy „słyszeć” to, co dzieje się we wnętrzu rzeczy ${ }^{18}$.

Świat inspiracji „przemawia” dźwiękiem wychodzącym od wewnątrz obrazu i „słyszalnym” na poziomie oglądu duchowego adepta. Dla tego ostatniego stanowi to pogłębienie wiedzy, a co za tym idzie, zrozumienia przekazu.

Trzeci stopień wyższego poznania wykorzystuje intuicję. „Otóż życie rzeczy w duszy to intuicja”" ${ }^{" 19}$. Wcześniej uzmysłowione ${ }^{20}$ wewnętrzne postrzeganie rzeczy

${ }^{15}$ Р. Штайнер, Сознание посвященных. Истинные и ложные пути духовного исследования, пер. С. Шнитцера, Лонгин, Ереван 2012, s. 18.

${ }^{16}$ Р. Штейнер, Пути к новому архитектурному стилю. „И здание становится человеком”, пер. О.Г. Прониной, КМК, Москва 2008.

${ }_{17}$ R. Steiner, Stopnie wyższego poznania, tłum. T. Mazurkiewicz, J. Prokopiuk, red. R. Reszke, Spektrum, Warszawa 1995, s. 10.

${ }^{18}$ Ibidem, s. 11.

${ }^{19}$ Ibidem, s. 12.

${ }^{20}$ Użycie przeze mnie słowa „uzmysłowiony” w opisie poziomu poznania intuitywnego jest przekornie zamierzone. Pomimo odrzucenia w stopniach poznania antropozoficznego władz zmysłowych, język współczesnego opisu tego zjawiska stanowi swoiste zwierciadło dla, z jednej 
możliwe jest poprzez intuicyjne jej rozpoznanie, połączenia się procesu poznawczego nadawcy i odbiorcy. W owym procesie wpływ „ja” oglądającego zostaje praktycznie zawieszony. Podobnie jak to się dzieje w przypadku doświadczenia mistycznego, późniejsza próba werbalizacji opisu wypada blado, zakładając sytuację, w której jest ona w ogóle możliwa.

Wymienione trzy etapy wtajemniczenia nie muszą hierarchicznie funkcjonować w świadomości i doświadczeniu twórcy. Kategoria twórczej aktywności jest już niezbędna na etapie poznania imaginatywnego i może, a nawet powinna, prowadzić do rezultatu twórczego, jakim jest dzieło sztuki.

\begin{abstract}
W swym rozwoju światopoglądowym (filozoficznym i ezoterycznym) Steiner nawiązał do chrześcijańskiej i europejskiej tradycji inicjacyjnej (od starożytnej gnozy po różokrzyżowstwo). Etapy jego rozwoju duchowego przebiegały następująco: 1) okres goetheanistyczny 1882-1892, obejmujący refleksję nad myślą Goethego - głównie nad jego alternatywną metodologią przyrodoznawczą (teoria metamorfozy roślin i zwierząt oraz Farbenlehre); 2) 1892-1901, okres, w którym - w polemice z Kantem i w krytycznym nawiązaniu do Fichtego Wissenschaftslehre - tworzy „filozofię wolności”; 3) etap różokrzyżowo-teozoficzny, który obejmuje lata 1901-1912 (na ten okres przypada różokrzyżowa inicjacja myśliciela); 4) 1912-1925, w tym okresie Steiner tworzy i rozwija własną wiedzę duchową (Geisteswissenschaft), tj. antropozofię i jej wyższe stadium - michaelityzm ${ }^{21}$.
\end{abstract}

Okres goetheanistyczny zaowocował między innymi pracą systematyzującą i omawiającą badania i poglądy niemieckiego myśliciela, którą ukończył Steiner w roku 1897. Nosiła ona tytuł Goethes Weltanschauung (Światopoglq̨d Goethego, GA 006) ${ }^{22}$. Zostały tu omówione również zagadnienia bezpośrednio powiązane z koncepcją sztuki i artysty, które później legły u podstaw estetyki antropozoficznej. Badania, jakie prowadził Goethe nad światem przyrody, a właśnie to jest kluczowe w antropozoficznym goetheaniźmie, opierały się na całościowym ujęciu bytu naturalnego, przejawiającego się w różnych formach jako jego odmiany. Człowiek w takim ujęciu nie tyle jest sprzężony z naturą, ile stanowi jej część. Poznanie zatem dokonuje się nie w ujęciu przeciwstawnym jednej badanej formy w stosunku do drugiej, lecz w ich relacji i podobieństwie do siebie. Proces poszukiwania odpowiedzi prowadzi od początkowego ujęcia całości i zmierza do skupienia uwagi na częściach składowych. Istota zjawisk wynika z ich relacji do całości jako elementów z tej całości wyprowadzonych. Źródło poznania tkwi dla Goethe w kategorii doświadczenia, które zawiera w sobie świat idei. Doświadczenie duchowe obejmuje

strony, zmiany kodu komunikacyjnego, a z drugiej - niewystarczającego namysłu nad atrofią niektórych słów współcześnie używanych.

${ }^{21}$ J. Prokopiuk, Szkice antropozoficzne. Chrześcijańska droga poznania świata duchowego, Studio Astropsychologii, Białystok 2003, s. 10.

${ }^{22}$ Inne prace Steinera, podejmujące zasygnalizowaną tematykę: Einleitungen zu Goethes Naturwissenschaftlichen Schriften (GA 001), Grundlinien einer Erkenntnistheorie der Goetheschen Weltanschauung, mitbesonderer Rücksicht auf Schiller (GA 002). 
oglądem świat idei w taki sam sposób, w jaki świat fizyczny dostępny jest dla ludzkiego oka. Brak podziału między kategorią doświadczenia i światem idei stanowi tę właśnie zasadę, jaka różni propozycję Goethego od systemu zaproponowanego przez Friedricha Schillera. Dla przedstawiciela klasyki weimarskiej poznanie jest budowane dwukierunkowo - zewnętrznie poprzez obserwację i wewnętrznie poprzez rozumowanie/myślenie. Ten odcisk kantyzmu jest jednak przez Schillera z czasem przezwyciężany. Jego najważniejsze dzieło estetyczne, zatytułowane Listy o estetycznym wychowaniu człowieka ${ }^{23}$, powstawało w okresie ogromnego wpływu Goethego, a propozycje i pomysły były wymieniane korespondencyjnie między poetami ${ }^{24}$. Tym, co łączy rozbieżności, scala dwie propozycje oglądowe w jedno, okazuje się być kategoria sztuki i doświadczenia estetycznego. To właśnie w sztuce upatruje Goethe istotę poznania, które opiera się na formie postrzegania, przepełnionego wewnętrznymi przeżyciami człowieka. Sztuka jawi się jako najwyższy przejaw natury, z czego wynika, że tak pojęta twórczość jest twórczością naturalną. Zatem pojęcie twórczości jest kategorią wpisaną w człowieka, a nie wyborem poprzez pryzmat talentu czy umiejętności. „Sztuka musi porzucić rzeczywistość, z całą skromnością i odwagą wznosząc się ponad potrzebę; albowiem sztuka jest córką wolności i chce być posłuszna jedynie konieczności duchowej, nie zaś podążać za przymusem potrzeby materialnej” - pisał Schiller ${ }^{25}$. Dlatego w antropozofii sztuka i kategoria twórczości są swoistym przedłużeniem pracy duchowej adepta. Powstanie dzieła sztuki wiązało się u Goethego z wewnętrzną potrzebą, z przemożną i naturalną siłą, ze stawaniem się.

Kluczową kategorią w procesie poznania u obu myślicieli jest odczucie, zdolność odczuwania: „Wykształcenie zdolności odczuwania jest tedy palącą potrzebą naszej epoki nie tylko dlatego, że staje się środkiem, który uaktywnia lepsze poznanie życia, lecz także dlatego, że pobudza i ulepsza poznanie”26. Zdolność i potrzeba odczuwania zwracają zainteresowanie człowieka w kierunku poznania natury (tu prawdopodobnie zarówno tej materialnej jak i duchowej), co jest jednoznaczne z poznaniem siebie - „o ile zaś jest wrażliwy, o tyle ma rzeczywistość w sobie i stanowi siłę myślącą"27.

Antropozoficzna estetyka wykorzystuje w swoisty sposób również wspomnianą już wyżej Schillerowską polaryzację pomiędzy zewnętrzną obserwacją i wewnętrznym myśleniem. Kategorię doświadczenia sam filozof ujął również w teorii „popędów” przeciwstawnych: zmysłowego i popędu formy, łączonych w wyższą doznaniową konstrukcję za pomocą roboczo nazwanego popędu gry.

${ }^{23}$ F. Schiller, Pisma teoretyczne. „Listy o estetycznym wychowaniu człowieka” i inne rozprawy, tłum., przedm. J. Prokopiuk, Aletheia, Warszawa 2011.

${ }^{24}$ Prawdy szukamy obaj. Z korespondencji między Goethem i Schillerem, wyb., tłum., oprac. J. Prokopiuk, M.J. Siemek, Czytelnik, Warszawa 1974.

${ }^{25}$ F. Schiller, Pisma teoretyczne..., s. 43.

${ }^{26}$ Ibidem, s. 67.

${ }^{27}$ Ibidem, s. 89. 
„Popęd zmysłowy chce zmiany, żąda, żeby czas miał jakąś treść; popęd formy chce znieść czas, nie chce żadnej zmiany. Ten więc popęd, w którym oba tamte działają wspólnie (niech mi będzie wolno na razie, dopóki się z tego nie usprawiedliwię, nazwać go popędem gry), dążyłby do tego, aby znieść czas w czasie, pogodzić stawanie się z bytem absolutnym i zmianę z tożsamością”. Dalej dodaje: „Przedmiot popędu gry, przedstawiony w jednym ogólnym zarysie, można więc nazwać żywym kształtem; pojęcie to służy do oznaczenia wszelkich estetycznych właściwości zjawisk, jednym słowem, do określenia tego, co w najszerszym znaczeniu nazywamy pięknem"28. Ową teorię popędów Rudolf Steiner przeniósł na szersze pojmowanie wpływu prądów duchowych na jestestwo człowieka: popęd zmysłowy określił jako impuls lucyferyczny, popęd formy jako impuls arymaniczny, a tym co miało je neutralizować i wypracowywać nową jakość przez połączenie, był impuls chrystusowy ${ }^{29}$.

Z całościowego oglądu i doświadczania natury wyrasta w systemie Goethego koncepcja metamorfozy jako idei - idealnej prarośliny, formy, która przejawia się we wszystkich odmianach roślinności i tym samym daje możliwość jej odkrycia, a raczej specyficznego „ujrzenia” idei jako źródła ${ }^{30}$. Ta propozycja pojmowania procesu przemiany i procesu stawania się legła u podstaw całej antropozofii. Dzięki temu podstawową zasadą stała się zasada wolnego wyboru, zasada indywidualnej kompilacji ujęcia antropozofii w świadomości jej wyznawcy. Adept wkraczający na drogę antropozofii nie odrzuca swoich dotychczasowych doświadczeń, lecz odnajduje dla nich miejsce w ujęciu antropozoficznym, co daje mu możliwość spojrzenia na dokonania z innego, duchowego punktu widzenia. Wydaje się, że tak właśnie było w przypadku Karola Homolacsa. W jego poszukiwaniach znaczenia i wartości procesu twórczego wyraźnie występują nawiązania do koncepcji Goethego i Schillera. W traktacie Zasada harmonii w sztuce i w życiu Homolacs pisze:

W sztuce odsłaniać się może najbardziej tajemnica samego tworzenia i dlatego rozpatrywanie przejawów artystycznych prowadzi niejako bezpośrednio w utajoną treść rzeczy i może naprawdę zbliżyć do zrozumienia rzeczywistości ${ }^{31}$.

Wyraźnie koresponduje to z doświadczeniem Goethego w zetknięciu się z mistrzami sztuki włoskiej ${ }^{32}$. Również Homolacs upatrywać będzie w sztuce formy przejawiania się idei, a próby jej poszukiwania będzie łączył z istotą przeżycia

28 Ibidem, ss. 91, 93.

29 Zob. S.O. Prokofieff, Misterium Michaela, tłum. M. Waśniewski, Genesis, Gdynia 2016.

30 Estetyka antropozoficzna przyjmuje również goetheańską naukę o barwach. Zob. J.W. Goethe, Wybór pism estetycznych, wyb., oprac., wstęp T. Namowicz, PWN, Warszawa 1981.

31 K. Homolacs, Zasada harmonii w sztuce $i$ w życiu, nakł. własny, Kraków 1936, s. 16.

32 Doświadczenie i wrażenie, jakie wywarła na Goethego sztuka włoska, opisuje poeta w swoich dziennikach podczas podróży po Włoszech, wydanych później drukiem. Zob. J.W. Goethe, Podróż włoska, tłum. H. Krzeczkowski, PIW, Warszawa 1980. 
estetycznego $^{33}$ : „Nakarmić ducha może jedynie idea zaklęta w formę”34. Jeśli bliskie Homolacsowi jest poszukiwanie przejawów „goetheańskiej” formy wyrażania się idei, to sposób jej wyodrębnienia nie łączy się wyłącznie z doświadczeniem, lecz prowadzi poprzez złączenie poziomów przeciwstawnych: wewnętrznego oglądu idei i formy jej zewnętrznego przejawiania się. Energia, powstająca przy ujarzmieniu sił odrębnych prowadzi do głębokiego przeżycia estetycznego i w konsekwencji może objawić się jako nowa forma - dzieło sztuki.

Widzimy tedy, że w twórczości estetycznej występują dwie przeciwne sobie siły. Jedną z nich stanowi dążenie do jedności, do uzgodnienia, do związania i drugą stanowi dążenie do urozmaicenia, wzbogacenia, rozczłonkowania. Pierwsza ma swoje źródło w jednolitej wewnętrznej idei, druga w wielości i różnorodności zjawisk zewnętrznych. Na przecięciu tych dwóch przeciwnych sił jawi się właśnie „harmonijna forma”, która jednoczy w sobie obydwie siły przeciwne i sprzęga je nierozerwalnie ze sobą ${ }^{35}$.

Tak pojęta koncepcja sztuki i dzieła sztuki przeciwstawia się w oglądzie Homolacsa propozycjom estetycznym, nieuwzględniającym wewnętrznego, czyli duchowego aspektu twórczości, niebędącym swoistą wykładnią przejawiania się świata duchowego w przestrzeni materialnej.

Tylko więc w duchu tkwi jedność wszechobejmująca - tylko w duchu narodzić się może to, co jest podłożem stylu, a wszelkie nadzieje, że uda nam się wycisnąć prawdziwy jednolity styl z żelazo-betonu, czy z geometrii - z warunków ekonomicznych, z dążenia do wygody, że uda nam się go wyspekulować, wyestetyzować, są oczywiście złudnymi. Każda prawdziwa harmonia wytryska z tego wewnętrznego pra-źródła życia, gdzie kryje się tajemnica wszelkiej jedności, gdzie rodzi się „jaźń” człowieka ${ }^{36}$.

Zatem dzieło sztuki stanowi ujawnioną formę indywidualnego poznania duchowego i jest swoistym „hieroglifem” dla zaangażowanego odbiorcy. Innej możliwości dla Homolacsa nie ma. W tym tkwi kontekst antropozoficzny, który łączy własne doświadczenie artysty, związane z badaniami nad ornamentem ${ }^{37}$, z bardziej uniwersalną zasadą twórczą, odbijającą się w przestrzeni inicjacji duchowej. Za Steinerem określa Homolacs ewolucyjną projekcję sztuki, osnutą nie na jakości dzieła, lecz na przestrzeni czasowej jego powstania.

Artysta, kreślący figury ornamentalne, nie może ich czerpać z mózgu, gdzie bytują tylko sztywne już i zimne abstrakcje, dociera on jedynie swoją mroczną intuicją do tych sił, które budują jego własny organizm i określają tam rytm krwi, rytm oddechu, rytm ge-

${ }^{33}$ W poglądach obu twórców niemieckich, przeżycie estetyczne stanowi podstawową kategorię, znakująca prawdziwość dzieła sztuki. Zob. Prawdy szukamy obaj...

${ }^{34}$ K. Homolacs, Zasada harmonii..., s. 35.

35 Ibidem, s. 11.

${ }^{36}$ Ibidem, s. 13.

37 „Losy pokierowały moje życie w ten sposób, że poświęciłem się badaniom teoretycznym w zakresie plastyki, a w szczególności w zakresie ornamentu”. Ibidem, s. 7. 
stu, rytm głosu. [...] sztuka była dla człowieka dawnych epok sprawą ogromnej wagi. Treść wyłowiona z najgłębszych pokładów duszy krzepła w nieprzeliczone kształty artystyczne i stawała się objawieniem zewnętrznym ${ }^{38}$.

Artysta z okresu na przykład paleolitu różnił się od współczesnego nie umiejętnością wyrażania i zdolnościami artystycznymi, lecz sposobem pojmowania rzeczywistości go otaczającej. Był to proces duchowy i intuicyjny, pozbawiony ogromnego wpływu intelektu, podczas gdy właśnie ten ostatni charakteryzuje sztukę XX wieku. Zatem nie chodzi tu o jakość, lecz właśnie o doświadczenie, które ujmowało ideę natury (Goethe). Zmiana w procesie postrzegania jaka zachodzi na przestrzeni wieków, nie jest w systemie antropozoficznym degradowana, lecz wykorzystywana w propozycji budowy nowych form doświadczenia. W tym kierunku zmierza również myśl Karola Homolacsa. „Sztuka była od początku świata szkołą, w której ludzkość kształciła swoje poczucie społeczne - i dlatego, jak zaznaczyłem na wstępie, była zawsze sztuką plemienną, względnie narodową"39. Z tego też powodu do swoich badań nad sposobem nauczania sztuki w szkole i rozwijaniu postawy estetycznej u dzieci przyjmuje Homolacs antropozoficzną wykładnię pedagogiczną.

Okres międzywojenny w Polsce odznaczył się szeregiem nowych propozycji nauczania w ramach systemów kształcenia szkolnego. Skomplikowana sytuacja na mapie świata, kryzys myśli i gospodarki kapitalistycznej, popularyzacja nauk psychologicznych i chęć odzyskania równowagi wzmogły potrzebę zmiany kształcenia nowych członków społeczeństwa. Pedagogika antropozoficzna nie była wówczas jedyną propozycją. Reformatio systemów pedagogiki w Europie i na świecie miał swój początek pod koniec XIX wieku i prężnie działał do lat 30. XX wieku ${ }^{40}$. Dzieła czołowych przedstawicieli były chętnie tłumaczone na język polski (Georg Kerschenstein, Helen Parkhurst, Jean Piaget, Oskar Pfister, Adolphe Ferriere i in.).

Dla przykładu, z popularnym wówczas nurtem „Nowego Wychowania” ${ }^{41}$ współbrzmiała propozycja amerykańskiego filozofa i pedagoga Johna Deweya. W Polsce myśliciel szybko zyskał zwolenników ${ }^{42}$, a nieco później również przeciwników ${ }^{43}$. W roku 1921 pojawia się przekład pedagogicznego dzieła Deweya Zasady moralne w wychowaniu, w 1924 roku Szkoła a społeczeństwo, w 1929 - Moje pedagogiczne

38 Ibidem, ss. 48, 59.

39 Ibidem, s. 65.

40 J. Sobczak, „Nowe Wychowanie” w polskiej pedagogice okresu drugiej Rzeczypospolitej (1918-1939), WSP w Bydgoszczy, Bydgoszcz 1998.

41 Na gruncie polskim w nurt „Nowego Wychowania” włączyli się między innymi Maria Grzegorzewska, Józef Chałasiński, Bogdan Nawroczyński.

42 Zainteresowanie propozycją Deweya pojawiło się również po II wojnie światowej. Zob. J. Pieter, System pedagogiczny Johna Dewey'a, Wydawnictwo Instytutu Pedagogicznego, Katowice 1946.

43 R. Taubenszlag, Ujęcie krytyczne zasad szkoły pracy J. Deweya, Książnica-Atlas, LwówWarszawa 1929. 
credo, a tytuł Szkoła i dziecko doczekał się nie tylko wydania, ale i kilku wznowień. Pojawiały się również tłumaczenia dzieł filozoficznych Deweya Jak myślimy czy Filozofia a cywilizacja. Jednak to właśnie system pedagogiczny amerykańskiego myśliciela zawładnął polskimi umysłami ${ }^{44}$.

Swoją zbliżoną do behawioryzmu, a opartą na filozoficznym problemie doświadczenia propozycję nauczania osnuł Dewey na teorii refleksyjnego myślenia, którą treściwie nazywał problemem.

We wszelkim myśleniu refleksyjnym znajdziemy składniki te same. Są nimi: poczucie trudności (I), orientacja w nowym położeniu (II), przypuszczenia o możliwościach wybrnięcia (III), wyprowadzenie wniosków z tych przypuszczeń (IV), wreszcie dalsza obserwacja i eksperyment prowadzący albo do przyjęcia, albo też do odrzucenia przypuszczeń, a zarazem do zamknięcia problemu $(\mathrm{V})^{45}$.

Rozwiązywanie problemów możliwe jest dzięki doświadczeniu, stwierdzał Dewey. Zatem rola nauczyciela polega na tym, aby udostępnić dziecku warunki możliwe do zdobywania doświadczenia oraz podsuwać materiał (problem) do przemyśleń.

Jeżeli umiemy odnaleźć popędy i czynne nawyknienia dziecka, jeżeli potrafimy zająć je pracą metodyczną i owocną, dając im właściwe środowisko, nie będziemy potrzebowali troszczyć się zbytnio o jego zainteresowania - one się same sobą zajmą” - pisał Dewey ${ }^{46}$.

W uniwersyteckiej szkole doświadczalnej, jaką prowadził Dewey w Chicago teoria łączyła się z praktyką: „Dzieci w tej szkole miały zupełną swobodę ruchów. Niekrępowane przepisami dyscypliny zachowywały się jak w domu. Jedne z nich szyły, inne tkały, jeszcze inne zajmowały się stolarką itp.”47 Zasada kształcenia była zdecydowanie socjologiczna, ponieważ dążyła do takiego stanu świadomości jednostki, która czuje odpowiedzialność bycia i funkcjonowania w społeczeństwie i pracy na jego korzyść i rozwój. Z tego powodu dominowała nauka umiejętności podstawowych (pisanie, czytanie, liczenie), a później pojawiały się takie przedmioty, jak: historia, geografia, nauka o przyrodzie, matematyka. W tym przeglądzie

${ }^{44}$ J. Dewey, Zasady moralne w wychowaniu, tłum. W. Hofman, Zakład Narodowy im. Ossolińskich, Lwów-Warszawa 1921; J. Dewey, Szkoła a społeczeństwo, tłum. M. Lisowska, Książnica Polska, Lwów-Warszawa 1924; idem, Moje pedagogiczne credo. Szkoła a społeczeństwo, tłum. R. Czaplińska-Mutermilchowa, Książnica-Atlas, Lwów-Warszawa 1929; idem, Szkoła i dziecko, tłum. H. Błeszyńska, E. Wende i S-ka, Warszawa 1928 (inne: 1913, 1922, 1929, 1930, 1933, 2006); idem, Jak myślimy?, tłum. Z. Bastgenówna, Książnica-Atlas Lwów-Warszawa 1934; idem, Filozofia a cywilizacja, tłum. S. Purman, Wydawnictwo J. Przeworskiego, Warszawa 1938. W kontekście rozważań nad sztuką warto dodać, że istnieje również polskie tłumaczenie książki Deweya Sztuka jako doświadczenie, jednak jest to już późne wydanie. Zob. idem, Sztuka jako doświadczenie, tłum. A. Potocki, Zakład Narodowy im. Ossolińskich, Wrocław 1975.

45 J. Pieter, System pedagogiczny..., s. 24.

46 J. Dewey, Szkoła i dziecko, s. 86.

${ }^{47}$ Ibidem, s. 53. 
wyraźnie brakowało literatury, sztuki, muzyki, tańca z tego względu, że łączył je Dewey z pojęciem kontemplacji, które w jednolitym, dobrze prosperującym społeczeństwie nie stanowi wartości samej w sobie. Dlatego też znikoma ilość literatury i historii sztuki pojawiała się w klasach wyższych w formie uświadamiającej istnienie takich obszarów myśli ludzkiej.

Kolejną interesującą wówczas znawców propozycją był przynależący do „Niemieckiej Pedagogiki Reformy” (1890-1933) Ruch Wychowania Artystycznego (die Kunsterzieherische Bewegung). Podstawą nauczania było uwzględnienie stopnia wrażliwości dziecka na świat. Dostrzegano wspólne wyznaczniki geniuszu dziecka i artysty. Były również osoby niechętne takiej propozycji pedagogicznej. Stefan Kunowski (1909-1977), pedagog, profesor Katolickiego Uniwersytetu Lubelskiego, bardzo nieprzychylnie wypowiadał się o rozwijaniu u dziecka swoistych sił duchowych, łącząc to z wpływami masońskimi oraz niekorzystnym odziaływaniem teozofii i antropozofii właśnie ${ }^{48}$.

W gąszczu różnorodności nowych form i propozycji pedagogicznych wydaje się, że również wartą uwagi jest idea pedagogiki antropozoficznej, która w latach międzywojennych dopiero się rozwijała i w Polsce była dostępna raczej tylko dla członków i sympatyków PTA. Na dziś dzień istnieje już do dyspozycji zainteresowanego czytelnika obszerna publikacja na temat historii rozwoju ruchów ezoterycznych w Polsce w latach 1890-193949. Ograniczę się tu zatem do zaledwie kilku faktów. Początek powstawania pierwszych, wówczas jeszcze nieformalnych polskich grup antropozoficznych przypada na rok 1913, w którym to Steiner zakłada Towarzystwo Antropozoficzne. Kolejne dziesięciolecie funkcjonowało pod znakiem systemowej organizacji istniejących polskich ognisk antropozoficznych. W roku 1923 jedna z czołowych postaci polskiej antropozofii Luna Drexler zakłada, za zgodą Steinera i Allgemeine Anthroposophische Gesellschaft (AAG), Powszechne Towarzystwo Antropozoficzne (PTA). Oficjalne dokumenty rejestracyjne noszą datę 6 marca 1924 roku. W ramach nowo zarejestrowanej organizacji działają Lwowskie Koło Polskiego Towarzystwa Antropozoficznego (przewodniczy Luna Drexler) i Krakowskie Koło Polskiego Towarzystwa Antropozoficznego im. Jana Łaskiego (przewodniczy Henryk Kunzek). Poza PTA niezależnie działa Koło

${ }^{48}$ S. Kunowski, Podstawy współczesnej pedagogiki, Wydawnictwo Salezjańskie, Warszawa 2004; J. Sobczak, „Nowe Wychowanie” w polskiej pedagogice...

${ }^{49}$ Polskie tradycje ezoteryczne 1890-1939. Teozofia i antropozofia, t. 1, red. M. Rzeczycka, I. Trzcińska, Wydawnictwo Uniwersytetu Gdańskiego, Gdańsk 2019; Polskie tradycje ezoteryczne 1890-1939. Formacje, ludzie, idee, t. 2, red. M. Rzeczycka, I. Trzcińska, Wydawnictwo Uniwersytetu Gdańskiego, Gdańsk 2019; Polskie tradycje ezoteryczne 1890-1939. Masoneria, t. 3, red. M. Rzeczycka, T. Cegielski, Wydawnictwo Uniwersytetu Gdańskiego, Gdańsk 2019; Polskie tradycje ezoteryczne 1890-1939. Źródła i dokumenty, t. 4, red. D. Oboleńska, Wydawnictwo Uniwersytetu Gdańskiego, Gdańsk 2019; Polskie tradycje ezoteryczne 1890-1939. Idee przewodnie, t. 5, red. M. Dobkowski, T. Cegielski, Wydawnictwo Uniwersytetu Gdańskiego, Wydawnictwa Uniwersytetu Warszawskiego, Gdańsk-Warszawa 2020; Polish esoteric traditions. Selected issues, ed. by A. Świerzowska, Gdańsk University Press, Gdańsk 2019. 
„Słowacki”, pod kierownictwem Wigi Siedleckiej. Pierwszym ważnym na skalę krajowej antropozofii wydarzeniem był zjazd antropozoficzny w Warszawie 23-29 października 1929 roku.

Już z tego krótkiego sprawozdania wyłania się skomplikowana struktura antropozoficzna, w ramach której szerzona była nauka Rudolfa Steinera wśród członków i sympatyków, co z kolei miało ogromny wpływ na kulturę polską. Antropozofowie tłumaczyli dzieła i wykłady Steinera na język polski, część z nich była opublikowana i dostępna szerokiemu kręgu czytelników ${ }^{50}$, część przeznaczona była wyłącznie do „wewnętrznego użytku” tylko dla członków PTA ${ }^{51}$. W tej jakże ciekawej i różnorodnej działalności znalazła się i pedagogika. Jednym z jej propagatorów był właśnie Karol Homolacs. Już w latach 20. XX wieku, będąc wykładowcą uczelni wyższej w Krakowie, prowadził malarz nieformalne antropozoficzne koło studenckie, gdzie mógł wykorzystywać doświadczenia rozwijającej się wówczas pedagogiki antropozoficznej. System nauczania w szkołach waldorfskich $^{52}$ rozbudowuje Steiner w latach 1919-192453, natomiast koncepcja nowego wychowania powstaje dużo wcześniej. Już w 1907 roku został opublikowany tekst pt. Die Erziehung des Kindes vom Gesichtspunkte der Geisteswissenschaft. Była to pedagogika oparta na uwzględnieniu i rozwijaniu duchowego świata dziecka. Propozycja całkowicie przeciwstawna systemowi Deweya, a jednak wydaje się, że oświeceniowa koncepcja filozoficzna - Bildung - w jakiś nieformalny sposób łączy te dwa dążenia do programowania nowej, lepszej rzeczywistości. Za Marią Janion Bildung używam w znaczeniu staropolskiego słowa „ukształcenie”54, tu

${ }^{50}$ Przywołuję zaledwie kilka przykładów: R. Steiner, Przygotowanie do nadzmysłowego poznania świata i przeznaczeń człowieka, z. 4 wyd. z upoważnieniem aut. przetł. J. Rundbaken, Gebethner i Wolff, Warszawa1912; idem, Zasadnicze podstawy nowego ustroju społeczeństwa i państwa, przekł. jedynie autoryz. J. Siedleckiej i T. Witkowskiego, Warszawa [s.n., 1927]; idem, Filozofja wolności: zarys podstawy nowoczesnego poglqdu na świat: wyniki badań duszy metodq przyrodoznawczq, z upoważn. aut. spolszczył M.K. Wołowski, F. Hoesick, Warszawa 1929; idem, Sedno kwestii społecznej, w autoryz. przekł. M.O. [Maria Paulina Orsetti] i M.W. [Marian Wołowski], skł. gł. Nasza Księgarnia, Warszawa 1938.

${ }^{51}$ R. Steiner, Zarys teorii poznania w światopoglqadzie Goethego, tłum. St. Walewski, maszynopis, zbiory prywatne, s. 119; idem, Teozofia (Człowiek i świat w świetle Antropozofii), tłum. St. Walewski, s. 166; idem, Mistyka w zaraniu nowoczesnego życia duchowego oraz jej stosunek do dzisiejszego poglqdu na świat, tłum. K. Homolacs, maszynopis, zbiory prywatne. Zob. również „Gnozis. Dwumiesięcznik” 1991, nr 1.

${ }_{52}$ Zob. F. Edmunds, Pedagogika Rudolfa Steinera. Szkoły waldorfskie na świecie i w Polsce, tłum. A. Konczewska, Spektrum, Warszawa 1996. Pierwsza szkoła waldorfska powstała w Niemczech w 1919 roku.

${ }^{53}$ Oto niektóre wykłady Steinera o wychowaniu: Allgemeine Menschenkunde als Grundlage der Pädagogik (GA 293), Erziehungskunst. Methodisch-Didaktisches (GA 294), Menschenerkenntnis und Unterrichtsgestaltung (GA 302), Die Methodik des Lehrens und die Lebensbedingungen des Erziehens (GA 308), Die Kunst des Erziehens aus dem Erfassen der Menschenwesenheit (GA 311) i in.

${ }^{54}$ M. Janion, M. Żmigrodzka, Odyseja wychowania. Goetheańska wizja człowieka w „Latach nauki i latach wędrówki Wilhelma Meistra”, Aureus, Kraków 1998, s. 51. „Powtórzmy: oznacza 
pojmowanego jako proces zdobywania wiedzy, samokształcenie, doświadczenie i wynikająca z tego samorealizacja. Oba systemy, Deweya i Steinera, bez wątpienia dążą do wykształcenia nowego człowieka poprzez ukształtowanie w nim i rozwinięcie właściwych zdolności, nabywanych nie tylko w szkole, ale i przez całe życie. W tym zestawieniu pedagogika antropozoficzna wydaje się jednak być dużo bardziej pogłębiona i uniwersalistyczna. Warto przywołać tu wypowiedź Michaiła Bachtina, który rozpatrując ideę Bildung w jej literackiej odmianie Bildungsroman (powieść wychowawcza), podaje zestaw istotnych tekstów literackich, myśl ową rozwijających.

Gatunek powieści określany jako „powieść wychowawcza” (Erziehungsroman lub Bildungsroman) występuje w wielu różnorodnych wariantach. Zazwyczaj wylicza się tu następujące główne przykłady jego odmian (w porządku chronologicznym): Cyropiedię Ksenofonta (starożytność), Parzivala Wolframa von Eschenbacha (średniowiecze), Gargantuę i Pantagruela Rabelais’go oraz Simplicissimusa Grimmelshausena (epoka Odrodzenia), Telemaka Fenelona (neoklasycyzm), traktat pedagogiczny Rousseau’a Emil (ze względu na znaczny udział elementów powieściowych), Agatona Wielanda, Lebensgeschichte Tobias Knaut's des Weisen Wezela, Lebenslaufe nach aufsteigender Linie nebst Beilagan Hippela, Wilhelma Meistra Goethego (obie powieści), Tytana Jeana Paula (a także kilka innych jego utworów), Dawida Copperfielda Dickensa, Głodowego pastora Raabego, Zielonego Henryka Godfryda Kellera, W czepku urodzonego Pontoppidana, Lata chłopięce i Młodość Tołstoja, Zwykłq historię i Obłomowa Gonczarowa, Jana Krzysztofa Romain Rolanda, Buddenbroków oraz Czarodziejskq górę Tomasza Manna i in. ${ }^{55}$

Znalazły się tu dwa skrajnie polaryzacyjne utwory, które miały przemożny wpływ na przywołane wyżej systemy pedagogiczne: Parzival (Parsifal) Wolframa von Eschenbacha - wychowanie antropozoficzne ${ }^{56}$ i traktat pedagogiczny Rousseau’a Emil - nurt „Nowego Wychowania”57.

Goethe pojmował właściwie określony proces wychowawczy jako swoistego rodzaju połączenie, kategorię scalającą wewnętrzny, duchowy świat jednostki z przystosowaniem społecznym, czemu dał wyraz w powieści Lata nauki i lata wędrówki

ona [idea Bildung - D.O.] kształtowanie pełnego człowieka poprzez rozwinięcie umysłowych i moralnych dyspozycji dziecka i młodego człowieka oraz przez przyswojenie przez niego właściwych danemu społeczeństwu wzorów zachowań obyczajowych”. Ibidem, s. 55.

${ }_{55}$ M. Bachtin, Estetyka twórczości słownej, tłum. D. Ulicka, PIW, Warszawa 1986, s. 298.

${ }^{56}$ Koncepcja przygód Parsifala jako drogi inicjacyjnej była wielokrotnie nie tylko poruszana przez samego Rudolfa Steinera, ale i znalazła swoje odzwierciedlenie w dziełach literackich i naukowo-teoretycznych antropozofów różnej narodowości. Zob. na przykład: A. Bieły, Kocio Letajew, kompozycje sceniczne Vasyla Kandinskiego, J. Rogosz-Walewska, Hubert czy prace teoretyczne: R. Meyer, Zum Raum wird hier die Zeit. Die Gralsgeschichte, W.J. Stein, Weltgeschichte im Lichte des Heiligen Gral i in.

${ }^{57}$ To właśnie Emil Rousseau’a i koncepcja Lwa Tołstoja o złączeniu idei nowego wychowania z życiem stają się punktem odniesienia dla przedstawicieli „Nowego Wychowania”. Zob. J. Sobczak, „Nowe Wychowanie” w polskiej pedagogice..., s. 20. 
Wilhelma Meistra. Te same założenia postawił przed sobą Schiller, pracując nad Listami o estetycznym wychowaniu człowieka. Ta sama myśl towarzyszyła Steinerowi, kiedy czytał lekcje i wykłady dla przyszłych nauczycieli szkół waldorfskich. Ideę ową odnalazł również Homolacs, czemu dał wyraz w przywoływanych wyżej tekstach teoretycznych, objaśniając koncepcję nauczania poprzez sztukę, kształcącą w człowieku przyszłą postawę społeczną i będącą ratunkiem dla przyszłych losów Polski. W tych trzech aspektach warto spojrzeć na myśl Karola Homolacsa.

\section{Literatura}

Bachtin M., Estetyka twórczości słownej, tłum. D. Ulicka, PIW, Warszawa 1986.

Dewey J., Filozofia a cywilizacja, tłum. S. Purman, Wydawnictwo J. Przeworskiego, Warszawa 1938.

Dewey J., Jak myślimy?, tłum. Z. Bastgenówna, Książnica-Atlas Lwów-Warszawa 1934.

Dewey J., Moje pedagogiczne credo. Szkoła a społeczeństwo, tłum. R. Czaplińska-Mutermilchowa, Książnica-Atlas, Lwów-Warszawa 1929.

Dewey J., Szkoła a społeczeństwo, tłum. M. Lisowska, Książnica Polska, Lwów-Warszawa 1924.

Dewey J., Szkoła i dziecko, tłum. H. Błeszyńska, E. Wende i S-ka, Warszawa 1928.

Dewey J., Sztuka jako doświadczenie, tłum. A. Potocki, Zakład Narodowy im. Ossolińskich, Wrocław 1975.

Dewey J., Zasady moralne w wychowaniu, tłum. W. Hofman, Zakład Narodowy im. Ossolińskich, Lwów-Warszawa 1921.

Didi-Huberman G., Przed obrazem. Pytanie o cele historii sztuki, tłum. B. Brzezicka, Słowo/ obraz terytoria, Gdańsk 2011.

Dziemidok B., Główne kontrowersje estetyki współczesnej, Wydawnictwo Naukowe PWN, Warszawa 2012.

Edmunds F., Pedagogika Rudolfa Steinera. Szkoły waldorfskie na świecie i w Polsce, tłum. A. Konczewska, Spektrum, Warszawa 1996.

„Gnozis. Dwumiesięcznik” 1991, nr 1.

Goethe J.W., O niemieckiej architekturze, w: Teoretycy, artyści i krytycy o sztuce 1700-1870, wybór, przedm. i koment. E. Grabska, M. Poprzęcka, PWN, Warszawa 1974.

Goethe J.W., Podróż włoska, tłum. H. Krzeczkowski, PIW, Warszawa 1980.

Goethe J.W., Wybór pism estetycznych, wyb., oprac., wstęp T. Namowicz, PWN, Warszawa 1981.

Gut T., Andrej Belyj. Symbolismus, Anthroposophie Ein Weg, Rudolf Steiner Verlag, Dornach 1997.

Homolacs K., Zasada harmonii w sztuce i w życiu, nakł. własny, Kraków 1936.

Janion M., Żmigrodzka M., Odyseja wychowania. Goetheańska wizja człowieka w „Latach nauki i latach wędrówki Wilhelma Meistra”, Aureus, Kraków 1998.

Kandinsky und München. Begegnungen und Wandlungen 1896-1914, ed. A. Zweite, Prestel Verlag, München 1982.

Kandyński W., O duchowości w sztuce, wstęp M. Bill, tłum. S. Fijałkowski, Państwowa Galeria Sztuki, Łódź 1996. 
Komunikaty Polskiego Towarzystwa Antropozoficznego, Warszawa, listopad 1938 rok, Goetheanum Archiv A.02.008.001.

Kunowski S., Podstawy współczesnej pedagogiki, Wydawnictwo Salezjańskie, Warszawa 2004.

Oboleńska D., De Imaginatione. О эзотерической имагинации в русской культуре начала XX века, Wydawnictwo Uniwersytetu Gdańskiego, Gdańsk 2014.

Oboleńska D., Emblems as hieroglyphs of the imagination. "The Black Square” by Kazimir Malevich, „Studia Humanistyczne AGH” 2017, t. 16/4.

Oboleńska D., Rzeczycka M., Ezoteryczne inspiracje Hilmy af Klint (1862-1944), „Przegląd religioznawczy” 2016, nr 1.

Oboleńska D., Путь к посвящению. Антропософские мотивы в романах Андрея Белого, Wydawnictwo Uniwersytetu Gdańskiego, Gdańsk 2009.

Pieter J., System pedagogiczny Johna Dewey’a, Wydawnictwo Instytutu Pedagogicznego, Katowice 1946.

Polish esoteric traditions. Selected issues, ed. by A. Świerzowska, Gdańsk University Press, Gdańsk 2019.

Polskie tradycje ezoteryczne 1890-1939. Teozofia i antropozofia, t. 1, red. M. Rzeczycka, I. Trzcińska, Wydawnictwo Uniwersytetu Gdańskiego, Gdańsk 2019.

Polskie tradycje ezoteryczne 1890-1939. Formacje, ludzie, idee, t. 2, red. M. Rzeczycka, I. Trzcińska, Wydawnictwo Uniwersytetu Gdańskiego, Gdańsk 2019.

Polskie tradycje ezoteryczne 1890-1939. Masoneria, t. 3, red. M. Rzeczycka, T. Cegielski, Wydawnictwo Uniwersytetu Gdańskiego, Gdańsk 2019.

Polskie tradycje ezoteryczne 1890-1939. Źródła i dokumenty, t. 4, red. D. Oboleńska, Wydawnictwo Uniwersytetu Gdańskiego, Gdańsk 2019.

Polskie tradycje ezoteryczne 1890-1939. Idee przewodnie, t. 5, red. M. Dobkowski, T. Cegielski, Wydawnictwo Uniwersytetu Gdańskiego, Wydawnictwa Uniwersytetu Warszawskiego, Gdańsk-Warszawa 2020.

Prawdy szukamy obaj. Z korespondencji między Goethem i Schillerem, wyb., tłum., oprac. J. Prokopiuk, M.J. Siemek, Czytelnik, Warszawa 1974.

Prokofieff S.O., Misterium Michaela, tłum. M. Waśniewski, Genesis, Gdynia 2016.

Prokopiuk J., Szkice antropozoficzne. Chrześcijańska droga poznania świata duchowego, Studio Astropsychologii, Białystok 2003.

Schiller F., Pisma teoretyczne. „Listy o estetycznym wychowaniu człowieka” i inne rozprawy, tłum., przedm. J. Prokopiuk, Aletheia, Warszawa 2011.

Sobczak J., „Nowe Wychowanie” w polskiej pedagogice okresu drugiej Rzeczypospolitej (1918-1939), WSP w Bydgoszczy, Bydgoszcz 1998.

Steiner R., Filozofja wolności: zarys podstawy nowoczesnego poglq̨du na świat: wyniki badań duszy metodq przyrodoznawczq, z upoważn. aut. spolszczył M.K. Wołowski, F. Hoesick, Warszawa, 1929.

Steiner R., Mistyka w zaraniu nowoczesnego życia duchowego oraz jej stosunek do dzisiejszego poglq̨u na świat, tłum. K. Homolacs, maszynopis, zbiory prywatne.

Steiner R., Przygotowanie do nadzmysłowego poznania świata i przeznaczeń człowieka, z. 4 wyd. z upoważnieniem aut. przetł. J. Rundbaken, Gebethner i Wolff, Warszawa 1912. Steiner R., Sedno kwestii społecznej, w autoryz. przekł. M.O. [Maria Paulina Orsetti] i M.W. [Marian Wołowski], skł. gł. Nasza Księgarnia, Warszawa 1938. 
Steiner R., Stopnie wyższego poznania, tłum. T. Mazurkiewicz, J. Prokopiuk, red. R. Reszke, Spektrum, Warszawa 1995.

Steiner R., Teozofia różokrzyżowców, tłum. M. Waśniewski, Genesis, Gdynia 1996.

Steiner R., U bram teozofii, tłum. M. Waśniewski, Genesis, Gdynia 1997.

Steiner R., Zarys teorii poznania w światopoglądzie Goethego, tłum. St. Walewski, maszynopis, zbiory prywatne.

Steiner R., Zasadnicze podstawy nowego ustroju społeczeństwa i państwa, przekł. jedynie autoryz. J. Siedleckiej i T. Witkowskiego, Warszawa [s.n., 1927].

Taubenszlag R., Ujęcie krytyczne zasad szkoły pracy J. Deweya, Książnica-Atlas, LwówWarszawa 1929.

The occult in Russian and Soviet culture, ed. by B. Rosenthal, Cornell University Press 1997.

Соколов Б., Василий Кандинский. Эпоха великой духовности. Живопись. Поэзия. Театр. Личность, Букс МАрт, Москва 2016.

Штайнер Р., Сознание посвященных. Истинные и ложные пути духовного исследования, пер. С. Шнитцера, Лонгин, Ереван 2012.

Штейнер Р., Пути к новому архитектурному стилю. „И здание становится человеком”, пер. О.Г. Прониной, КМК, Москва 2008. 
